\title{
Technical Skills needed for an Informal Roadside Metalwork Fabrication Apprenticeship Practice
}

\author{
Halizah Awang*, Kankia Jamilu Danyaro, Zawawi Daud, W. Mohd Rashid W. \\ Ahmad
}

\begin{abstract}
There was range of disadvantages in the informal roadside metalwork fabrication apprenticeship practice in North Western Nigeria that includes the lack of appropriate Technical skills to better serve the society. The purpose of this research was to identify those Technical skills desirable for the informal roadside metalwork fabrication apprenticeship practice in Nigeria. To this effect an investigation was carried out through survey research, using questionnaire instrument and interview as entailed by methodological triangulation. The survey research was conducted using140 population of master craft persons from sampled workshops in seven states of North West geo-political zone of Nigeria. Interview of 10 participants was made, who were randomly selected from, Industry-based trainers, lecturers and instructors within the seven states in North Western Nigeria. The interviews were conducted to have a balance result. Open coding was made, followed by Axial coding, Selective coding was lastly made, results were interpreted as they complemented the descriptive results which entailed the methodological Triangulation method. To validate the results obtained from methodological triangulation, eleven Delphi panel of experts were involved. Binary analysis and Kendall's coefficient of concordance (Kendall's $W^{a}$ ) were used to measure and determine the consensus of the experts on the Technical skills items. Positive results were obtained because, the level of consensus between the participants was strong, the Technical Skills needed items score was 0.621 . The result also indicated an inter-judge reliability. Suggestions were made for the improvement of the sector, as the appropriate and valid Technical skills needed were outlined.

Keywords : Technical skills, apprenticeship practice, validation
\end{abstract}

\section{INTRODUCTION}

Informal roadside metal work fabrication apprenticeship is presently witnessing a rapid growth in Nigeria, for the fact that youth are making mass entry due to high competition in the formal apprenticeship practice. However apprentices trained under the system have low level of skill education that can better serve the needs of the society. The work done by Ehimen (2012) \& Udu (2015) identified among others, shortage of technical/vocational skills in the informal apprenticeship practice. Therefore, the research focused on identifying the technical skills needed for the informal roadside metalwork fabrication apprenticeship practice in Nigeria.140 crafts persons were used to answer a structured questionnaire. (MC Questionnaire).

Revised Manuscript Received on June 15, 2020.

* Correspondence Author

Halizah Awang*, Faculty of Technical and Vocational Education, Universiti Tun Hussein Onn Malaysia. Email: halizah@uthm.edu.my

Kankia Jamilu Danyaro, department, Name of the affiliated College or University/Industry, City, Country. Email: kankiajamilud@gmail.com

Zawawi Daud, Faculty of Civil and Environmental Engineering, Universiti Tun Hussein Onn Malaysia. Email: zawawi@uthm.edu.my

(C) The Authors. Published by Blue Eyes Intelligence Engineering and Sciences Publication (BEIESP). This is an open access article under the CC BY-NC-ND license (http://creativecommons.org/licenses/by-nc-nd/4.0/)
Creswell (2014) pointed out that an investigator provides a better understanding of the research problem when combines statistical trends (quantitative data)with stories and personal experience(qualitative data) to come up with strong answer to a certain problem of concern. The approach therefore used in this research was Methodological Triangulation and modified Delphi method to validate the technical skills items. This study constituted; Introduction, purpose of the study, research questions, methodology, results, Discussion and Conclusion. Suggestions for improvement of the sector were made, based on the explored Technical skills items.

\section{METHODOLOGY}

Questionnaire instrument was first adopted in this survey research. Purposive sampling involved identification and selection of individuals or groups of individuals that were proficient and well-informed with an occurrence of interest. The participants were 140 crafts persons and ten interviewed personnel. According to Byrne (2013) sample size below 100 was considered as small, between 100 and 200 was noted as medium and above 200 was regarded as large in quantitative research study. It was therefore ideal to have 140 as medium target participants. The participants were available and willing to participate, and had the ability to communicate experiences and opinions in an articulate, expressive, and reflective manner (lker, Sulaiman, Musa, Rukayya, \& Alkassim, 2016). The informal roadside metal work Master craftsperson (MC), in the North-West Nigeria had these characteristics. Therefore purposive sampling was adopted. First, research questions were analyzed using mean score and standard deviation. The data collected in quantitative was confirmed by interviewed experts through qualitative affirmation. The open ended questions were asked during the interview and were coded. Consistency was achieved in the qualitative research, by using quotations that objectively captured individual interviewed participant' experiences, credibility, confirmation and true value were obtained, indicating 'neutrality' thereby establishing completeness (Bekhet \& Zauszniewki, 2012), (Guba \& Lincon, 1989), which was similar to reliability in the quantitative research.

To this effect Qualitative Data coding processes were adopted. Open coding was first done. This according to Khairie (2012) is a process were by listening of the recorded interview is done, to make sense out of the interview, then, was written dawn. The 


\section{Technical Skills needed for an Informal Roadside Metalwork Fabrication Apprenticeship Practice}

Axial coding was followed, which according to him was to identify data that relate to one another. Comparison of similarities was merged of various respondent views on each construct or sub construct. Selective coding was then made as the final stage; the Technical skills needed were selected. High profile Delphi panel of experts were employed to validate the Technical skills items, by the use of two rounds. The next step was binary analysis of the results obtained from the panel of experts, as the first cycle. The result was tabulated by calculating the percentage using descriptive analysis in the SPSS. Any item with $80 \%-100 \%$ was regarded as consensus being reached for that item. Similarly, any item with $0 \%$ to $79 \%$ was regarded as consensus not reached (Franc, 2014; Davidson, 2013). Cycle two was made on the items yet to reach consensus. An e-questionnaire was developed in Google form, which was again sent to every panel member. It was significant to make the final questions as open as possible, this was to gain a strong response (Davidson,2013). Therefore Five point Likert scale was used, the value of which were as follows: 1= highly not needed,2=not needed,3=slightly needed,4=needed,5= highly needed. The questionnaire was emailed to each of the panel members. The response to the questionnaire was $100 \%$. Kendall's coefficient of concordance (Kendall's W ${ }^{\mathrm{a}}$ ) was used to measure and determine the level of consensus, through SPSS, thus outlining the validated Technical skills items that were needed for the informal apprenticeship practice.

\section{RESULTS}

The major statistics used in order to present information concerning the collective judgments of respondents, were measures of central tendency and level of dispersal, which is standard deviation. This was done through the use of SPSS. The research questions were analyzed using mean score and standard deviation. Craftsperson, mean scores were used in reporting the responses on degree of agreement and the most likely selected items as needed. Any item that gets 3.50 and above mean response was accepted as needed. Any response below 3.50 was rejected as not needed. Qualitative Data coding analysis was adopted. Open coding was first done, by listening of the recorded interview, to make sense out of the interview, then, was written dawn. The Axial coding was followed, which was to identify data that relate to one another. Comparison of similarities was merged of various respondent views on each construct or sub construct. Selective coding was then made as the final stage; the Technical skills needed were finally selected, which were validated using Modified Delphi panel of experts.

Table 1: Technical skills (safety practice items) correctly and safely

- Skill to setup gas welding equipment correctly and safely

- Skill to set oxy acetylene flame forgas welding correctly \& safely

- Skill ability in guiding mechanical activities using sensory signs

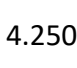

4.128

Table 1 was the summary of results of descriptive analysis constituting the mean, standard deviation, on; Technical skills needed (TSN) (safety practice items). These items were

Retrieval Number: C5326029320/2020@BEIESP DOI: 10.35940/ijeat.C5326.069520 Journal Website: www.ijeat.org outcome of Crafts person opinion on safety practice items needed in the informal roadside metalwork fabrication apprenticeship practice in Nigeria. It could be deduced that all items had mean scores above 3.50. Therefore, these items were recommended by crafts persons as needed. Interviews of experts on the items followed. Interview participants (P) (the Experts) were asked to comment on the needed technical skills of the Safety Practice items as shown in Table 2 .

Table 2: Interviewed participant comments on Technical skills (safety practice items)

\begin{tabular}{|c|c|}
\hline $\begin{array}{l}\text { Interview } \\
\text { participants (P) }\end{array}$ & $\begin{array}{l}\text { Comment of each interviewed } \\
\text { participant on the needed technical } \\
\text { skills of the Safety Practice items. }\end{array}$ \\
\hline (P1) & $\begin{array}{l}\text { "...Safety practice items in the technical } \\
\text { skills are all needed”. }\end{array}$ \\
\hline (P2) & $\begin{array}{l}\text { "...safety precaution and safety practice } \\
\text { should be giving a very good consideration". }\end{array}$ \\
\hline (P3) & $\begin{array}{l}\text { "...the items in the technical skills, the safety } \\
\text { practice, are, to my opinion needed", }\end{array}$ \\
\hline (P4) & $\begin{array}{l}\text { "...technical skills highly needed are item } \\
\text { 2, } 28 \text { and } 29 \text { all other items are needed in the } \\
\text { training" }\end{array}$ \\
\hline (P6) & $\begin{array}{l}\text { "...actually because of time factor let me } \\
\text { summarise it. I will start with safety } \\
\text { precaution which is very important" }\end{array}$ \\
\hline (P7) & $\begin{array}{l}\text { "...the items in all are needed, technical skills } \\
\text { item 2, (Skill ability to recognize danger) } 28 \\
\text { and } 29 \text { are highly need". }\end{array}$ \\
\hline (P8) & $\begin{array}{l}\text { "...ok you are highly welcome, so technical } \\
\text { skills highly needed are 2, } 28 \text { and } 29 \\
\text { all others are needed in the training". }\end{array}$ \\
\hline (P9) & $\begin{array}{l}\text { "...technical skills needed which include } \\
\text { safety practice are as well needed in the } \\
\text { training..." }\end{array}$ \\
\hline
\end{tabular}

All the items in the Safety Practice pointed out by the Craftsperson as needed were recommended by interviewed participants, however several interview participants emphasised item 2 in the safety practice of the Technical skill (Skill ability to recognize danger) as highly needed in the practice.

\begin{tabular}{|c|c|}
\hline \multicolumn{1}{|c|}{ Task } & Mean \\
\hline - Skill ability in getting ready to act mentally & 4.171 \\
physically \& emotionally & 4.150 \\
- Skill ability to recognize danger & 4.328 \\
- Acquire skill to recognize sound that & \\
indicates malfunctions & 4.142 \\
\hline
\end{tabular}

Table 3: Technical skills (Identification of Tools and Equipment items)
Published By:

Blue Eyes Intelligence Engineering \& Sciences Publication

677 (c) Copyright: All rights reserved.

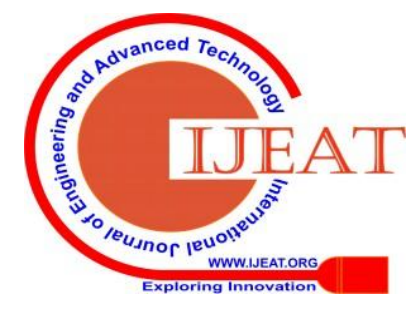


- Skill ability to identify welding equipment tools and materials

- Identify gas welding equipment and accessories/tools

- Identify different types of rivets and their correct applications.

- Identify the different riveting tools used in workshop

- Identify the tools and accessories needed for soldering and brazing operation

- Acquire skills to adapt, alter, reorganize, change or revise correctly

- Skills to prepare metal joint for arc metal welding in any giving situation

- Skills ability to prepare metal surfaces for gas welding process

Table 3 was the summary of results of descriptive analysis that constituted the mean, standard deviation on; Identification of Tools and Equipment items. It could be deduced that all items had mean scores above 3.50. Therefore, these items were recommended as needed by Crafts persons of the informal roadside metalwork fabrication apprenticeship practice in Nigeria. Interviews of experts were conducted to balance the result obtained as regards the items.

Interview participants (P) (the Experts) were asked to comment on the needed technical skills of the Identification of Tools and Equipment items as shown in Table 4.

\section{Table 4: Interview participant comments on Technical} skills (Identification of Tools and Equipment items)

\begin{tabular}{|c|c|}
\hline $\begin{array}{l}\text { Interview } \\
\text { participants (P) }\end{array}$ & $\begin{array}{l}\text { Comment of each interviewed } \\
\text { participant on the Identification of } \\
\text { Tools and Equipment items }\end{array}$ \\
\hline (P1) & $\begin{array}{l}\text { "...identification of tools and equipment, } \\
\text { items } \\
\text { are also needed especially item no 9, and 12", }\end{array}$ \\
\hline (P5) & $\begin{array}{l}\text { “...identification of tools and equipment also } \\
\text { needed especially number } 9 \text { and } 12 "\end{array}$ \\
\hline (P6) & $\begin{array}{c}\text { "...Identification of tools and equipment } \\
\text { is very important" }\end{array}$ \\
\hline (P10) & $\begin{array}{l}\text { "...technical skills highly needed are item } \\
\text { 2, } 28 \text { and } 29 \text { all other items are needed in the } \\
\text { training" }\end{array}$ \\
\hline (P6) & $\begin{array}{l}\text { "...the items in the identification of tools and } \\
\text { equipment in the technical skills are needed } \\
\text { especially item } 8 \text { and } 9 "\end{array}$ \\
\hline
\end{tabular}

From the forgone statements made in table 6.4 by the various interviewed experts, it could be realised that all items of the 'Identification of tools and equipment' were recommended as needed. However some were said to be highly needed. This declaration by the experts enriched and made better understanding of the data therefore better informed decisions were made.

Table 5: Descriptive analysis on Technical skills (Tools and Equipment usage items)

\begin{tabular}{|l|l}
\hline Task & Mean \\
\hline
\end{tabular}

- Weld metal pieces to form assembly of parts correctly

- Weld metal component using gas welding equipment

- Carryout arc weld in different positions

- Grinding off excess weld bead on welded joints without weakening the joint

- Carryout cold riveting of work pieces with a hand Riveting Machine

- Carryout hot riveting of work pieces with a hand riveting machine

- Rivet work piece with power riveting machine

- Prepare appropriately surface to be soldered or brazed

- Solder metal work pieces using electric soldering bits

- Solder metal work pieces using blow lamp

- Braze metal pieces using blow lamp

- Skills ability in acting, building, performing, implementing, recreating (manipulation)

- Skills ability in starting to learn complex skills through imitation and trial and error

- Skills ability in gaining confidence and proficiency in Learning complex skills

- Operate arc welding machine/equip to lay welding beads on metal pieces

- Skills ability in performing complex movement skillfully

- Skill ability in modifying movement patterns to fit specific requirements (adaptation)

- Skill ability in adapting, combining, constructing, coordinating creating (articulation)

- Skill ability in creating new movement pattern (origination)

- Skill ability in designing, developing, inventing, specifying (naturalisation)

- Acquire skills in correct usage of modern tools

- Acquire skills in correct usage of modern equipment

4.150

4.050

4.428

4.057

3.978

4.064

4.250

3.842

4.257

4.328

Table 5 was the summary of results of descriptive analysis that constituted the mean, standard deviation, on; Tools and Equipment usage items. It could be seen that all items had mean scores above 3.50. Therefore, these items were recommended as needed by Crafts persons of the informal roadside metalwork fabrication apprenticeship practice in Nigeria. Interviews of experts were conducted to complement the result obtained as regards the items. Interview participants (P) (the Experts) were asked to comment on the needed technical skills of Tools and Equipment usage items the response is in table 6 as shown below.

Table 6: Interviewed participant comments on Technical skills (Tools and Equipment usage items) \begin{tabular}{|l|l|} 
Interview & Comment of each interviewed participant
\end{tabular} participants (P) on the needed technical skills of Tools and Equipment usage items

(P1)
$\begin{aligned} & \text { "...tools and equipment usage duty, all the } \\ & \text { items are needed". } \\ & \text { (P2) } \\ & \text { usage are very important" }\end{aligned}$
Published By:
Blue Eyes Intelligence Engineering
\& Sciences Publication
(C) Copyright: All rights reserved.


Technical Skills needed for an Informal Roadside Metalwork Fabrication Apprenticeship Practice

\begin{tabular}{|c|c|}
\hline (P3) & $\begin{array}{l}\text { "...emphasis should be placed on item } 28 \text { and } \\
29 \text { in the tools and equipment usage duty, that } \\
\text { is, the skill ability in starting to learn complex } \\
\text { skills through imitation and trial and error, } \\
\text { skill ability in gaining confidence and } \\
\text { proficiency in learning complex skills } \\
\text { respectively.." }\end{array}$ \\
\hline (P5) & $\begin{array}{l}\text { "...In tools and equipment usages, duty, the } \\
\text { tasks are all needed with } 44 \text { being highly } \\
\text { needed". }\end{array}$ \\
\hline (P6) & $\begin{array}{l}\text { "...how to use the tools and equipment, is } \\
\text { very important especially in roadside } \\
\text { metalwork fabrication practice". }\end{array}$ \\
\hline (P7) & $\begin{array}{l}\text { "...tools and equipment usage task items are } \\
\text { needed with } 28 \text { and } 29 \text { as highly needed" }\end{array}$ \\
\hline (P8) & $\begin{array}{l}\text { “...technical skills highly needed are ... } 28 \text { and } \\
29 \text { ”. }\end{array}$ \\
\hline (P10) & $\begin{array}{l}\text { "...the items in the tools and equipment usage } \\
\text { are all needed with special regard to items } 28 \\
\text { and } 29 \text { which are highly needed. Obviously } \\
\text { this project work if implemented will take care } \\
\text { of haphazard apprentice training in the } \\
\text { informal roadside fabrication practice" }\end{array}$ \\
\hline
\end{tabular}

From what had been stated by the various Experts, it could be deduced that all items in the 'Tools and equipment usage' were needed. Moreover the items emphasized by interviewed experts as highly needed were; Skills ability in starting to learn complex skills through imitation and trial and error; and skills ability in gaining confidence and proficiency in learning complex skills.

Table 7: Descriptive analysis on Technical skills (Finishing process items)

\begin{tabular}{|l|c|}
\hline \multicolumn{1}{|c|}{ Task } & Mean \\
\hline - $\quad \begin{array}{l}\text { Skill ability in calibrating, completing, } \\
\text { controlling, Demonstrating, } \\
\text { executing, performing, showing } \\
\text { (precision) }\end{array}$ & 4.328 \\
- Acquire skills to dismantle and assemble & \\
$\quad$ components correctly & 4.150 \\
- Copying, following, repeating, replicating, & 4.321 \\
- $\quad$ Acquire skills ability for successful finishing & 4.321 \\
- $\quad$ Acquire skills to modify component to fit & 4.114 \\
- $\quad$ Acquire skills to measure correctly & 4.357 \\
- Acquire skills to mix correctly & 4.342 \\
- Acquire skills to organize correctly & 4.400 \\
- Acquire skills to manipulate correctly & 4.392 \\
- Acquire skills to manipulate correctly & 4.428 \\
- Acquire skills to mend correctly & 4.385 \\
\hline
\end{tabular}

Table 7 was the summary of results of descriptive analysis that constituted the mean, standard deviation on; Finishing process items. It could be observed that all items had mean scores above 3.50. Therefore, these items were selected as needed by Crafts persons of the informal roadside metalwork fabrication apprenticeship practice. Interviews of experts were carried out to complement the result obtained as regards the items of the finishing process.

Table 8: Interview participant's comments on Technical skills (Finishing process items)

\begin{tabular}{|l|l|}
\hline $\begin{array}{l}\text { Interview } \\
\text { participants } \\
\text { (P) }\end{array}$ & $\begin{array}{l}\text { Comment of each interviewed } \\
\text { participant on Finishing process items }\end{array}$ \\
\hline (P1) & $\begin{array}{l}\text { "...in the finishing process duty, the } \\
\text { tasks are all needed, with item 44 being } \\
\text { highly needed" }\end{array}$ \\
\hline (P3) & $\begin{array}{l}\text { "..finishing processes tasks, all items are } \\
\text { needed" }\end{array}$ \\
\hline (P6) & $\begin{array}{l}\text { "...after work finishing process is } \\
\text { very important." }\end{array}$ \\
\hline (P10) & $\begin{array}{l}\text { “...the finishing process items are } \\
\text { needed with item 44 being highly need" }\end{array}$ \\
\hline
\end{tabular}

From the statements made by the various Experts in Table 8, on the 'Finishing process' items of Technical Skills, it could be realized that all items of the finishing process were recommended as needed. More over item 44 was said to be highly needed. The item emphasized by experts as highly needed was acquire skills to measure correctly.

\section{VALIDATION OF THE INVESTIGATED TECHNICAL SKILLS.}

The set of Technical skills items identified by Crafts persons and interviewed experts were sent to Modified Delphi panel of experts for validation through first and second round.

\section{First round: Binary analysis}

Using the binary analysis, consensus was determined for the first cycle. Panel of experts responded to the questionnaire items that solicited their various opinions on the Technical Skills, rated as either 'Not needed' $=1$ and 'Needed' $=2$. This binary analysis results were tabulated by calculating the percentage using descriptive analysis in the SPSS. Items that consensus were reached on them were sorted, those not reached were sent back to the panel of experts as in the second round.

\section{Second round: Kendall's coefficient of concordance (Kendall's $\mathbf{W}^{\mathrm{a}}$ )}

Cycle 2 was made on the items yet to reach consensus. An e-questionnaire was developed in Google form, sent to every panel member. It was significant to make the final questions as open as possible, this was to gain a strong response.

Therefore Five point Likert scale was used, the value of which were as follows: $1=$ highly not needed, $2=$ not needed,3=slightly

needed,4=needed, $5=$ highly needed. The questionnaire was emailed to each of the panel

members. The response to the questionnaire was $100 \%$. Kendall's coefficient of concordance (Kendall's W) was used to measure and determine the level of consensus, through SPSS. 
Table 9: The Consensus Results of First (R1) and Second Rounds (R2)

\begin{tabular}{|c|c|c|c|c|}
\hline \multicolumn{5}{|c|}{ Table 6.10: Final consensus results } \\
\hline SNO & Rl: ND/NND/CSNR & R2: HA/LA & CONSENSUS & \\
\hline 1 & ND & HA & $\mathrm{ND}$ & \\
\hline 2. & NND & - & $\mathrm{DCD}$ & \\
\hline 3 & ND & - & ND & \\
\hline 4 & ND & - & $\mathrm{ND}$ & \\
\hline 5. & ND & - & ND & \\
\hline 6. & ND & - & $\mathrm{ND}$ & \\
\hline 7 & CSNR & HA & ND & \\
\hline 8 & $\mathrm{ND}$ & - & $\mathrm{ND}$ & \\
\hline 9. & $\mathrm{ND}$ & - & $\mathrm{ND}$ & \\
\hline 10. & $\mathrm{CSNR}$ & HA & $\mathrm{ND}$ & \\
\hline 11. & CSNR & $\mathrm{HA}$ & $\mathrm{ND}$ & \\
\hline 12. & $\mathrm{ND}$ & - & $\mathrm{ND}$ & \\
\hline 13. & ND & - & ND & - \\
\hline 14. & NND & - & DCD & \\
\hline 15 & ND & - & $\mathrm{ND}$ & \\
\hline 16. & CSNR & HA & $\mathrm{ND}$ & \\
\hline 17. & CSNR & $\mathrm{HA}$ & $\mathrm{ND}$ & \\
\hline 18. & CSNR & $\mathrm{HA}$ & $\mathrm{ND}$ & \\
\hline 19. & ND & - & $\mathrm{ND}$ & \\
\hline 20. & CSNR & HA & $\mathrm{ND}$ & \\
\hline 21. & CSNR & LA & $\mathrm{DCD}$ & \\
\hline 22. & $\operatorname{CSNR}$ & LA & $\mathrm{DCD}$ & \\
\hline 23. & CSNR & $\mathrm{HA}$ & $\mathrm{ND}$ & \\
\hline 24. & CSNR & LA & $\mathrm{DCD}$ & \\
\hline 25. & $\operatorname{CSNR}$ & $\mathrm{HA}$ & $\mathrm{ND}$ & \\
\hline 26. & $\operatorname{CSNR}$ & $\mathrm{HA}$ & $\mathrm{ND}$ & \\
\hline 27. & NND & - & $\mathrm{DCD}$ & \\
\hline 28. & ND & - & $\mathrm{ND}$ & \\
\hline 29. & ND & - & ND & \\
\hline 30. & ND & - & $\mathrm{ND}$ & \\
\hline 31. & NND & - & $\mathrm{DCD}$ & \\
\hline 32. & ND & - & $\mathrm{ND}$ & \\
\hline 33. & NND & - & DCD & \\
\hline 34. & CSNR & LA & $\mathrm{DCD}$ & \\
\hline 35 . & CSNR & $\mathrm{HA}$ & $\mathrm{ND}$ & \\
\hline 36. & $\mathrm{ND}$ & - & $\mathrm{ND}$ & \\
\hline 37. & $\mathrm{ND}$ & - & $\mathrm{ND}$ & \\
\hline 38. & $\mathrm{ND}$ & - & $\mathrm{ND}$ & \\
\hline 39. & $\operatorname{CSNR}$ & LA & $\mathrm{DCD}$ & \\
\hline 40. & $\mathrm{ND}$ & & $\mathrm{ND}$ & \\
\hline 41. & CSNR & HA & $\mathrm{ND}$ & \\
\hline 42. & $\mathrm{ND}$ & - & $\mathrm{ND}$ & \\
\hline 43. & ND & - & $\mathrm{ND}$ & \\
\hline 44. & ND & - & $\mathrm{ND}$ & \\
\hline 45. & $\mathrm{ND}$ & - & $\mathrm{ND}$ & \\
\hline 46. & ND & - & $\mathrm{ND}$ & \\
\hline 47. & NND & . & $\mathrm{DCD}$ & \\
\hline 48. & ND & - & $\mathrm{ND}$ & \\
\hline
\end{tabular}

ND: neaded; NND: not needed; CSNR: consensus not reached; HA: high agreement L A.: low agreement DCD: discarded.

The modified Delphi process is considered complete when consensus response rate is greater than $70 \%$. This has been outlined as in table 6.10. The total TSN items were 48. The consensus in Cycle 1 were 31 items, while in Cycle 2 were 11.Totaling 42 items. In this case the response rate needed to stop rounds was achieved, as it was $87.5 \%$. Out of 48 items identified by Master crafts persons and Interview participants, 37 were recommended(ND) as valid by the Delphi panel of experts, as 11 items were unanimously discarded (DCD) by the panel.

The Kendall's coefficient of concordance (Kendall's W), which ranges from 0 to 1 , indicating the degree of consensus reached by the panel (strong consensus for $W>0.7$; moderate consensus for $W=0.5$; and weak consensus for $W<0.3$ ) was run in SPSS. Table 6.7 portrayed among others, Delphi panel of expert's level of agreement on Technical Skills items, as Kendall's $\mathrm{W}^{\mathrm{a}}$ was 0.621 .

The scale of the coefficient of concordance indicated also that there were satisfactory level of coordination and agreement in the panel. This indicated the inter-judge reliability. This suggested that the panelists have scored items according to their needed importance, therefore agreed to each other. The process was completed as consensus has been clearly defined, valid Technical skills items were made visible (ND items).

\section{DISCUSSION}

Thirty-seven out of forty- eight items were validated, therefore recommended by modified Delphi panel of experts as needed in the practice. It is vital to make apprentices understand the safety requirements and standards. Welding, soldering, and brazing in fabrication processes present significant hazards, including exposure to hot materials, ultraviolet light, gases, fumes, noise, and heat stress. Therefore items validated should be taught comprehensively in the apprentice skill practice. Such item as number 2: 'Skill ability to recognize danger' stressed out as highly needed in the practice.

An apprentice should be coached to be able to deal with work hazards, accidents \& injuries, should be able to know the work hazards, should be able to respond in case of fire by using fire extinguishers and other techniques. Fire safety and hazards knowledge, should be taught practically: Causes of Fire; Fire Hazards; Process and respond in case of emergency; Types of fire extinguishers; Welding fires; Sparks and spatter: Should be able to use the fire extinguishers, fire blankets, water and sand. The essence is to remain safe and keep others safe as well, therefore recognizing danger and making precautionary measures is of importance, responding correctly in case of emergency is as well important. The apprentice should be able to know about the injuries knowledge of: Health hazards occurring due to fabrication processes, possible injuries that can occur during the practical. Should be able to know about the first aid during work its provision and emergency responses. An apprentice should remain conscious and provide first aid to his co worker who is suffering. He should know what to do in case of emergency. Keep the work place safe ensure proper ventilation systems, he should be able to understand the ventilation system, Ducting and its types, exhaust fans and smoke catchers. Welding plant should be placed where there is proper ventilation, keeping the environment smoke free. Skill ability to identify Arc and Gas welding equipment, tools and materials were also of high importance, as pointed out by the Craft persons. Apprentice should be able to know and understand the function of for example, regulators and their types and gas cylinders as well; Electrical connection of arc welding machine, receptacle, Gas Cylinders, their types and usage, Current flow; Insulators, connectors, and thimbles installations; Regulators installations, type of regulators. Back fire arresters function and their installation before start of work. He should be able to identify the suitable equipment, tools and materials for certain jobs. Item number 12; Identify the tools and accessories needed for soldering and brazing operations was also of importance. Apprentice ought to be able to identify the tools and accessories needed for soldering and brazing operations. Such as; soldering copper or Iron, Solder and flux. The apprentices ought to know the Brazing equipment tools and materials, such as; furnace, oxyacetylene torch, filler metals, fluxes etcetera.

'Skills ability in starting to learn complex skills through imitation and trial and error' is labeled also, as an item of importance. It is expected of the apprentice to learn complex skills, having gone through novice stage, advance beginner, to this stage of competency.

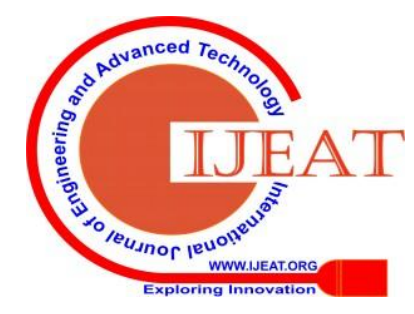




\section{Technical Skills needed for an Informal Roadside Metalwork Fabrication Apprenticeship Practice}

He should be able to arrange the tools and equipment required to perfume jobs that is, the tools required, the Machines required in a safe and precautious manner. This could be described as Guided response level. This explains the early stages in learning a complex skill that includes imitation and trial and error. Adequacy of performance is achieved by practicing. This level talk more on the apprentice, who face the challenges of new tasks, as he use (for example) a power brush just after observing Craftsperson demonstrate its use. He experiments with various ways to measure a given volume of lubricant for lubrication. He performs a mathematical equation as demonstrated by the Craftsperson. He follows instructions to construct a Jig, folding stainless steel chair, for example. This could be described as Mechanism stage which is an intermediate stage in learning a complex skill. Learned responses have become habitual and the movements can be done with some confidence and proficiency.

The ability to assembles, builds, calibrates, constructs, dismantles, displays, dissects, fastens, fixes, grinds, heats, manipulates, measures, mends, mixes, organizes, sketches etc should be demonstrated by the informal roadside metalwork fabrication apprentice. He should be able to use drilling machine, operate several machines in the workshop.

The 'skill ability in gaining confidence and proficiency in learning complex skills' is item number 29 which is also very essential. The apprentice in this stage organizes the job to execute on time and safely. He must plan the activity to execute the job appropriately. This is adaptation stage or skill maturity stage as described by Simpson (1972). Skills are now well developed and the individual can modify movement patterns to fit special requirements. The informal roadside metalwork fabrication apprentice can now adapts, alters changes, rearranges, reorganizes, revises, and varies a certain job.

Apprentice at this stage is expected to be able to create new movement patterns to fit a particular situation or specific problem. He arranges, combines, composes, constructs, creates, designs, originates. He Learns outcomes; emphasize creativity based upon highly developed skills. This is the stage of graduation as Craftsperson. Item number 44 'Acquire skills to measure correctly' was also an item of significance. It entails that an apprentice must learn the measuring tools with practical accuracy such measuring tools as: Steel rules, Steel Tape, Vernier Calipers, Callipers' (Internal \& external), Micrometer, Gauges, Solid Steel Square, Surface Gauge, etcetera. He must be able to solve simple math's questions must understand and read drawings, must know; Addition and Subtractions, Multiplications and Divisions, Diameter and Circumference finding, Percentage finding, Conversion of Inches to Metric to Inches, Kinds of Lines, Kinds of Angles, Drawing the Radius, Isometric views etcetera.

\section{CONCLUSION}

The needed Technical Skill items identified were of utmost importance in the practice. Therefore the research work promote TVET activities and was, an attempt to promote the level of Technical Skill of the informal sector operators of the

Informal apprenticeship practice. This also could promote productivity of the informal roadside metalwork fabrication practice for the betterment of lives of youths in particular areas.

\section{ACKNOWLEDGEMENTS}

It is pertinent to acknowledge the vast encouragement and support vested on the researcher for the successful completion of this research by Research Supporting Grant Scheme (PPG; K004), from Universiti Tun Hussein Onn Malaysia, FPTV staff, the entire community of UTHM and the Centre for Graduate Studies (CGS). Of course, the effort made by several experts and crafts persons in the series of interviews and attending to the questionnaire is appreciated.

\section{REFERENCES}

1. Byrne (2013) A genome-wide association study of sleep

2. Habits and insomnia - Wiley Online Library. Retrieved on 29/012017 from: onlinelibrary.wiley.com/doi/10.1002/ajmg.b.32168/abstract

3. Bekhet, A.K., Zauszniewswki, J.A., (2012) Methodological Triangulation: An Approach to Understanding Data. Retrieved on 25/10/2018. From: https//pdf.semanticscholer.org

4. Creswell, John W. (2014) Research Design: Qualitative, Quantitative, and Mixed Methods Approaches. 4th ed. Thousand Oaks, California: SAGE

5. Publications, 2014.Retrieved https://adams.marmot.org/Record/.b40623245

6. Devid, M. and Sutton, C.D. (2012) Social Research basics. London: SAGE Publications. Apprentices vocational potentiality as mediator. Apprentice's vocational ability mediates between these variables and the predicting variable, skilled apprentice with decency.

7. Davidson (2013) The Delphi Technique In Doctoral Research: Considerations and Rationale. University of Phoenix, USA. www.intellectbase.org/journals 13 Published by Intellect base International Consortium, USA

8. Ehimen, Ehijele, Ehimen (2012) Modalities For Enhancing Mode Of Training Metalwork

9. Craftmen In Apprenticeship Practice In Edo State. ATBU Journal of Science, Technology and Education, [S.l.], v. 1, n. 1, p. 129-136, jun. 2012. ISSN 2277-0011. Available at:

10. http://www.atbuftejoste.com/index.php/joste/article/ view/79 Franc, (2014) Delphi technique: The Do Nots and Why Nots. Retrieved on 7/12/2018 from, https://www. YouTube

11. Guba E.G, Lincon Y.S, (1989) Fourth Generation Evaluation. Sage publication, Newbury park, CA

12. Hair, J , F, Black, W,C Babin, B,J,\& Anderson, R,E (2010). Multivariate Data Analysis.Vectors

13. Hasson, F., Keeney, S., \& McKenna, H. (2000). Research guidelines for the Delphi survey technique. Journal of Advanced Nursing, 32 (4), 1008-1015

14. Hubert and Dreyfus (1991) Sustaining Non-rationalised practices: Body mind Power and Situational Ethics. An interview with Hubert and Stuart Dreyfus. Oxford: Praxis, International, No.1, pp93-113.

15. lker Etikan, Sulaiman Abubakar Musa, Rukayya Sunusi Alkassim (2016). Comparison of Convenience Sampling and Purposive Sampling. American Journal of Theoretical and Applied Statistics. Vol. 5, No. 1, 2016,

16. ILO, (2011). Skills for Employment, Upgrading Informal Apprenticeship Systems, International Labour Office, A Resource Guide for Africa (Geneve, ILO).

17. Khairie, M. (2012) Qualitative Data process; Retrieved from Youtube.https/www.youtube.com on 30/8/2018.

18. Loannis Koskoses (2009) Communicating Information Systems Goals: A case in Internet Banking Security. Retrieved on 25/10/2018 from https://www.researchgate.net
Published By:

Blue Eyes Intelligence Engineering \& Sciences Publication

681 (C) Copyright: All rights reserved.
Retrieval Number: C5326029320/2020@BEIESP DOI: 10.35940/ijeat.C5326.069520 Journal Website: www.ijeat.org 
Kankia Jamilu Danyaro work as a lecturer at Hassan Usman Kaisina Polytechnic, Kaisina State, Nigeria. Currently, he is doing his $\mathrm{PhD}$ at Universiti Tun Hussein Onn Malaysia.

research focuses on alleviating problems associated with water pollution issues from industrial wastewater and landfill leachate. His latest interest is on natural adsorbent material in water and wastewater treatments.

Performing Arts Safety Manual (2014) retrieved on 5/10/2018 from; https://www.ucop.edu/environment-health-safety/_files/perform-arts/tmweld.pdf

Simpson, E. J. (1966/72) Psychomotor Domain Retrieved on

$$
\text { 22/01/2017 from: }
$$

http://www.businessballs.com/bloomstaxonomyoflearningdomains.htm\#blo om\%27s\%20taxonomy\%20over view

Udu (2015) Apprenticeship Orientation And Performance Of MicroBusinesses In Ebonyi State, Nigeria. European Journal of Biology and Medical Science ResearchVol.3, No.6, pp.1-11, December 2015 Published by European Centre for Research Training and Development UK.

\section{AUTHORS PROFILE}

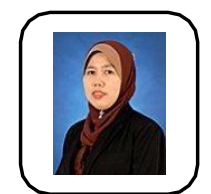

Halizah Awang received the $\mathrm{PhD}$ in educational curriculum from Universiti Sains Malaysia in 2010 Since January 2011, she has been with Faculty of Technical and Vocational Education, Universiti Tun Hussein Onn Malaysia as an Associate Professor. Her research focuses on curriculum and instruction in

TVET, Job and career

development in TVET and teaching and learning in TVET.

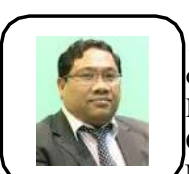

Zawawi Daud works as an Associate Professor at Faculty of Civil and Environmental Engineering, Universiti Tun Hussein Onn Malaysia. Dr. Zawawi received his $\mathrm{PhD}$ in Civil Engineering (Environment) from Universiti Sains Malaysia in 2009. Dr. Zawawi's

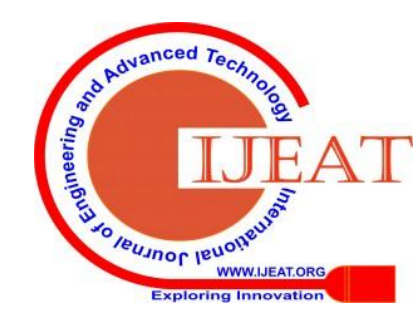

